\title{
Implications of Foreign Ownership on Journalistic Quality in a Post-Communist Society: The Case of Finance
}

\author{
Martine Robinson Beachboard and John C. Beachboard \\ Idaho State University, Pocatello, Idaho, USA
}

\author{
beacmart@isu.edu beach@isu.edu
}

\begin{abstract}
When freedom from Communism largely eliminated overt government censorship of newspapers, other political and business pressures appeared. Consequently, Southeastern European newspaper publishers faced threats to financial viability and editorial integrity. The editor-in-chief of one newspaper in the former Yugoslavian republic of Slovenia claims to have found freedom from political and advertiser influence after a global media conglomerate invested in the publication. Notably, the business daily Finance is the only hard-news start-up to survive in the eleven years since Slovenia gained independence from the Republic of Yugoslavia. This research paper offers a provocative example where international investment appears to have contributed to the democratizing of media in a post-communist society. The paper is not intended to argue that foreign media investments are necessarily beneficial but to suggest some circumstances in which foreign media investment can be advantageous to the democratic aspirations of a society.
\end{abstract}

Keywords: Media ownership, post-communist journalism, theories of the press, media and democratization, Yugoslavian press, Slovenian news media.

\section{Background and Motivation for This Study}

"Democracy is the worst form of government except all those other forms that have been tried."

$\sim$ Winston Churchill

Churchill's wry observation regarding the relative merits of alternative forms of government might well be paraphrased to apply to alternatives for organizing and funding a society's journalism: Market-driven journalism, as commonly practiced in western democracies, appears to be the worst form of journalism except for all those other forms that have been tried. The authors' recent research into the evolving practice of print journalism in Slovenia and the specific investigation of the business news publication Finance offer some thought-provoking insights regarding potential costs and benefits of market-driven

Material published as part of this publication, either on-line or in print, is copyrighted by the Informing Science Institute. Permission to make digital or paper copy of part or all of these works for personal or classroom use is granted without fee provided that the copies are not made or distributed for profit or commercial advantage AND that copies 1) bear this notice in full and 2) give the full citation on the first page. It is permissible to abstract these works so long as credit is given. To copy in all other cases or to republish or to post on a server or to redistribute to lists requires specific permission and payment of a fee. Contact Publisher@InformingScience.org to request redistribution permission.

journalism.

Two streams of critical research relating to the shortcomings of market-driven journalism are especially relevant to the purposes of this study. One stream laments the gradual diminution of quality hard-news reporting in the public interest and its increasing replacement with superficial information, sensationalistic news and celebrity gossip (Ansolabe- 
here \& Iyengar, 1997; McChesney, 1999; Postman, 1986). A second critical stream addresses the implications of media ownership by large and transnational conglomerates under the loosely defined rubrics of media globalization and cultural imperialism (Demers, 1999; Downing, 1996; Hamelink, 1994; Herman \& McChesney, 1997; Hollifield, 2001; International Press Institute [IPI], 2004; McPhail, 1987; Schiller, 1976; Thompson, 1997; Tomlinson, 1991) A chief concern identified in the media globalization literature is that increasing consolidation, globalization and deregulation of media conglomerates has been "preparing the way for the inexorable advance of a 'one-dimensional' capitalist culture" (Tomlinson, 1991, p. 120). The aforementioned research streams are situated largely within the context of theories of press roles and functions in society. These theories represent extensions of the classic work by Siebert et al in the 1950s concerning the archetypical ways societies arrange relationships between government and news media and the economic support of media production.

In the traditional application of social sciences, one does not claim that a single case study can serve to support or refute a body of theory, and that is not our purpose here. This paper represents an interpretive analysis of a particular case. Our intent is to shed light on the particulars that too often are lost in the process of conventional theorizing.

\section{Three Slovenian Start-Up Failures, Three Successes}

The authors believe that hard-news journalism plays important roles in society and that quality journalistic practice must be nurtured to more effectively serve the needs of societies. We share the concerns of scholars and social critics who fear that the profit-maximizing behavior of media conglomerates diminishes quality of news reporting and the pluralism of voices in the marketplace of ideas (McManus, 1994). Questioning whether western models of journalism such as libertarian or social responsibility (Siebert, Peterson \& Schramm, 1956) will necessarily prevail in the democracies emerging from formerly socialist European nations, the authors conceived a project to investigate the evolution of print journalism in the former Yugoslavia. We selected Slovenia to study due to its relative economic and political stability and its stronger western orientation relative to other formerly socialist nations as representing a midpoint between former eastern-bloc nations and western democracies in terms of economic prosperity and cultural attitudes and traditions.

After Slovenia declared its independence from Yugoslavia in June 1991, its expresident Milan Kučan made these predictions concerning the world around him: "Nothing will remain the way it was. Naturally, newspapers are the exception" (Frankl, 2004). Some observers hoped the new democracy would see a proliferation of new news dailies, increasing the quality and diversity of reporting. In fact, there have been changes in the Slovenian media space, though perhaps not entirely consistent with Kučan's vision. The major news publications existing prior to Slovenian independence remain today: Delo and Dnevnik published in Ljubljana, Večer published in Maribor, and the alternative weekly Mladina. Three post-independence general-interest newspapers started in the 1990s failed: Slovenec, Republika and Jutranjik. While an analysis of these failures is beyond the scope of this paper, multiple sources indicated that the Slovenian public was offended by strong political positions reflected in these new papers' editorial content (Bervar, 2001; Frank1, 2005; Hrvatin, Kucic \& Petkovic, 2004; Slovenian Journalist, 2004).

Meanwhile, three newly established special-interest publications succeeded: Slovenske Novice, which has the largest circulation of any newspaper in the country $(107,000)$ but is considered to be of "yellow" tabloid quality (Bervar, 2001; Slovenian Journalist, 2004), Ekipa sports daily, and the business daily Finance. The last of these, Finance, published in Ljubljana, provides a particularly revelatory case (Eisenhardt, 1989; Yin, 1994) for empirically examining a specific example of foreign ownership and its influence on the availability of news content in Slovenia. 


\section{Research Question}

Given widely published concerns regarding the shortcomings of private media ownership and the perils of international media conglomerates it was interesting to find a newspaper editor in a small, newly democratized country who welcomes ownership by a foreign media conglomerate because of the political freedom that he perceived such an investment as providing. This case studies a relatively new and successful start-up newspaper in the Southeastern European republic of Slovenia which separated from Yugoslavia and started down a path toward a western form of democracy in 1991. This case, which represents one element of a broader inquiry, led to the development of the following research question: What can be learned about the implications of foreign ownership for journalism quality from the examination of a post-independence start-up news publication in an emergent democracy?

In writing this case, the authors neither explicitly challenge nor support the critical narratives informing global media studies. Rather, we seek to provide a fair and transparent interpretation of the experiences and perspectives of actors directly involved in the production of news. We seek to represent "local knowledge" (Geertz, 1985) and in so doing to provide an additional perspective for those seeking to construct theoretical bases for the formulation of national policies governing ownership, production and dissemination of news-related media.

\section{Methodology: An Interpretivist Case-Study Design}

This research employs a case-study design intended to provide a fine-grained examination of the creation and operation of the Slovenian business daily newspaper Finance. The purpose is less to extend theory than to apply it by representing and necessarily interpreting the lived experience of actors directly involved with the production of news products. The research takes an interpretive philosophical approach illustrated by an analogy developed by Slife and Williams (1995, p. 87). In describing interpretive ways of knowing, they ask the reader to consider the difference between a map of a city and an informal account of that city provided by a resident. The map, while admittedly an interpretation, represents an abstraction of an objective reality, depicting "only those features of the place that would remain unchanged if no one lived there (e.g., patterns of streets, layouts of buildings)." The informal account is quite different although ultimately as informative or even more so. While "necessarily personal, incomplete and biased..." the personal account might describe the best places to eat or sections of towns to avoid. By providing such description, the informal account "gives meaning to the town, from a native's point of view." It is certainly not the only description or possible interpretation, but legitimate nonetheless.

As are many researchers, we are interested in the consequences of increasing dominance of media production by transnational conglomerates, in particular attempting to understand the effects of foreign media ownership on local news production and consumption. The Finance case merited study because it appeared to contradict commonly held assumptions concerning transnational media domination and ownership, highlighting a continuing need to study the particular as well as the general and to employ multiple research methods (Hollifield, 2001; March, Sproull \& Tamuz, 1991; Stake, 1994; Yin, 1994).

Research activities and processes included in this study can be grouped into the following categories:

- Case selection. Finance is notable as the only daily hard-news publication established in post-socialist Slovenia that has survived until today. We acknowledge that Finance, as a business news publication, occupies a market segment distinct from the newspapers that failed. Despite this limitation, it merits study due to its approach in selecting and presenting content and its increasing readership in political and business sectors. 
- Data collection. While documentary evidence was examined, the primary data source consisted of face-to-face and telephone interviews with a key informant, the managing editor at Finance. Relying on the managing editor as the primary source of information concerning Finance's business strategy and editorial approach was particularly appropriate in this case due to his in-depth knowledge of the publication and its history and because of his leadership role in executing the business strategy and establishing the editorial approach. While key informant interviews are an established method for collecting qualitative data, the authors recognized limitations associated with relying on the perceptions of a single individual. Accordingly, interviews were conducted with additional journalists at Finance and competitive publications, Slovenian academicians and officials from the Slovenian Ministry of Information. The selection of participants was purposive, and snowball techniques identified additional informants. Interviews were organized around the research question but were conducted using the "active interview" approach (Holstein \& Gubrium, 1994). With the permission of study participants, researchers tape-recorded interviews. The primary author conducted follow-up telephonic interviews and e-mail exchanges with multiple study participants. While the authors did not promise participants confidentiality, we felt some revelations might be sensitive enough to merit protection. Thus, while we are able to specifically identify the sources of quotes used, we have attempted to be discreet about revealing some identities.

- Data analysis. Analysis consisted primarily of the creation of a case narrative that seeks to accurately reflect interviewee perceptions respecting answers to the research question. The objective was to develop an accurate and rich description of a phenomenon as seen through the eyes of the study participants. Related literature is referenced to provide useful context.

- Validity and reliability assessments. The authors used the results of the unstructured interviews to develop narrative themes representing participants' varied perspectives. Where possible, we used participant checks to test whether our interpretation of interview data fairly represents participant views (Altheide \& Johnson, 1994; Miles \& Huberman, 1994; Patton, 2002).

These procedures demonstrate the authors' commitment to employing disciplined data elicitation and analysis techniques consistent with recommendations of leading qualitative researchers and methodologists.

Given the interpretive philosophy guiding the design and execution of this study and consistent with a recommended approach for writing qualitative research, we present the study findings first and then introduce relevant literature in our interpretation of the data (Creswell, 1994).

In the remainder of this paper, we first briefly describe Slovenia's unique history. Next we provide an overview of the Slovenian print media landscape in which Finance competes. We then describe the publication's mission, history and services. This context provides a backdrop for encountering the chief editor's perspective regarding the role played by Finance in the Slovenian media market, and the impact foreign investment has had on Finance's development and the quality of services it is able to provide to its readership. The paper offers an interpretation of the case within the context of theories of the press.

\section{Historical Context of Slovenian Media}

While the authors acknowledge their own affinity for examining historical context, study participants also insisted that an appreciation of Slovenia's unique historical context was vital to understanding current challenges and practices: First you must understand our history, they would say; it is different; it influences what we do, how we think today. Slovenians consider their republic to 
be unique among Yugoslavian republics, distinct from Central and Eastern European states emerging from Soviet domination. Slovenia has been more westward-oriented. Not only is it geographically the most western territory in the former Yugoslavia, but German nobility ruled local populations beginning before $1000 \mathrm{AD}$, and German immigrants established towns and businesses in the region. Slovenia had the strongest economy of the Yugoslavian republics. Josip Broz Tito's "third way" to socialism permitted a degree of regional autonomy and private-sector economic activity even in a system of centralized political control (Campbell, 1980; Lydall, 1987). In the view of study participants, these factors helped prepare Slovenia to make the transition to a democratic, market-oriented economy.

Slovenian print media, even under communism, had some tradition of market support. In 1948 Tito broke away from Stalin. The communist party was interested in media but did little to fund media other than public television. The communist government did provide a safety net which kept newspapers from going bankrupt, but major earnings came from subscriptions and advertising (Frankl, 2004; Hrvatin et al., 2004).

In independent Slovenia, there are half a dozen major news publications, about the same number as under communism. However, there are not as many different editorial perspectives as this number might imply due to media ownership concentration in terms of political and economic influence. As Hrvatin et al. (2004) explain, a significant lack of ownership transparency can conceal the identities of media "controlling" interests. They indicate extensive direct media crossownership and further indirect cross-ownership at parent-company levels. More alarmingly, they report strong ties between leading political and business interests, suggesting the potential for political and economic collusion. Members of media governing boards "are chairpersons of the largest Slovenian companies (which are also the largest advertisers), owners of advertising agencies and chairpersons or supervisory board members of the largest banks. This means that media power is closely connected with economic power..." (Hrvatin et al., 2004, p. 477).

Finance has survived and grown for more than a decade with an injection of foreign mediaconglomerate investment and a modern approach to writing and editing. The newspaper has a typical press run of 24 tabloid-size pages and a paid circulation of 10,000. By way of comparison, the most widely read serious newspaper in Slovenia, the generally respected Delo, has a circulation of 90,000. Slovenia's news publications have the circulation sizes and numbers of employees indicated at Table 1. Alternative though similar figures are available from Freedom House (2003).

\begin{tabular}{|c|c|c|c|}
\hline \multicolumn{4}{|c|}{ Table 1: Major Slovenian Publications' Circulation and Staff Sizes* } \\
\hline Publications & Circulation & Readership & Employees (Journalists) \\
\hline \multicolumn{4}{|l|}{ Daily Newspapers } \\
\hline Slovenske Novice & 107,000 & 355,000 & $\mathrm{n} / \mathrm{a}$ \\
\hline Delo & 90,000 & 237,000 & $452(165)$ \\
\hline Dnevnik & 66,000 & 159,000 & $226(71)$ \\
\hline Večer & 62,000 & 170,000 & $231(71)$ \\
\hline Ekipa & 25,000 & $\mathrm{n} / \mathrm{a}$ & $\mathrm{n} / \mathrm{a}$ \\
\hline Finance (business daily) & 10,000 & 36,000 & $110(50)$ \\
\hline \multicolumn{4}{|l|}{ Weekly Publications } \\
\hline Mladina & 19,300 & 102,000 & $\mathrm{n} / \mathrm{a}$ \\
\hline Mag & 17,000 & 58,000 & $\mathrm{n} / \mathrm{a}$ \\
\hline Žurnal (free distribution) & 214,000 & $\mathrm{n} / \mathrm{a}$ & $\mathrm{n} / \mathrm{a}$ \\
\hline
\end{tabular}




\section{The Finance Case Description}

This section examines the particular case of Finance, a business daily newspaper whose primary focus is on reporting economic and economically relevant news to the Slovenian business community. In Finance's own words, it seeks to offer businesspeople "breaking business news, exclusive coverage" and a determination "always to be the first to know and the one to bring superior understanding of the business environment to all interested" (Finance, 2005). In addition to reporting economic news originating in Slovenia, Finance acts as a Slovenian language conduit for reporting international business news to the Slovenian business community and, with the addition of English language pages to its print and new-media products, provides Slovenian business news to the international business community.

Finance's core product and revenue source is its print-version daily. It has expanded its reach by adding traditional- and new-media products to reach a wider market and promote subscription to its print edition. The website at $<$ www.finance-on.net $>$ reaches 50,000 unique users per month, a "Business Morning" daily web-based e-mail service has more than 20,000 subscribers, and a textonly e-mail product called "Radar," which matches information to user interests, has 3,000 users. The Finance brand authors a television morning show of three to four minutes, and twice weekly radio programs. While relatively small, Finance views itself as a multi-media information services company. "We do not consider ourselves only as a daily newspaper. We are a service company. We distribute information and opinions and entertainment," said editor-in-chief Peter Frankl (2004).

The inception of the Finance publication dates to the first year following Slovenian independence. Upon the country's 1991 declaration of independence from Yugoslavia and with the advent of democracy, a Slovenian publishing group called Gospodarski Vestnik (GV) saw an opportunity to create a business-oriented publication focusing on the financial information needs of Slovenia's emerging market economy. Finance, funded in part with government privatization funds, was first published as a biweekly specialty newspaper in 1992. In 1999, GV partnered with Dagens Industri (DI), selling a 48.6-percent interest in Finance. This DI is the business press segment of one of the largest European media conglomerates, the Swedish publishing group Bonnier AB which owns newspapers in Denmark, Estonia, Latvia, Lithuania, Poland, Russia, Slovenia and Sweden as well as a 50-percent stake in the Austrian business daily Wirtschaftsblatt (Bonnier Group, 2006; Frankl, 2005). The strength of the editorial product combined with the injection of Bonnier capital enabled Finance to start appearing five times a week in 2001. In 2002 Finance showed its first profit. "It was a small profit. But it is not a large project. Total investment in the enterprise was about 2.8 million euros" (Frankl, 2004). Bonnier subsequently bought out Gospodarski Vestnik, which dissolved in February 2005; thus, Bonnier is now essentially the 100 percent owner of Finance.

The company Časnik Finance, d.o.o. is managed by Jurij Giacomeli as managing director with Frankl as editor-in-chief. Frankl began his journalism career in 1990 with major daily Delo. He later worked for Gospodarski vestnik business weekly, joining Finance at its inception and becoming its editor-in-chief in 1995. Newspaper employees total 110 people in all departments; 50 of these workers are journalists.

The original readers of Finance were entrepreneurs, managers from large companies, college students, "decision makers and opinion leaders and officials in state institutions... and more affluent readers who are attractive to advertisers." Later the readership appeal broadened to include "people who deal with money - which is almost everyone," as Frankl said. In contrast to reading habits in some of their neighboring countries, Slovenians tend to remain loyal to a single daily newspaper. Consequently, most readers of Finance also read one of the major dailies, usually Delo. 


\section{The Economics of Finance}

Finance may serve the public interest, but certainly it is not purely a public service project. "If we want to contribute to society, yes, we also have a purpose to make money," Frankl said. Some 70 percent of Finance's revenues come from advertising and 30 percent from circulation sales. Major advertiser categories include banking concerns, information and communications technology firms, computer manufacturers, construction, financial investment firms, automotive, travel and alcohol. Much of the advertising is business-to-business. A four-color, full-page ad in the print edition costs 3,200 euros. Other 2005 advertising options and rates are displayed at Table 2. The newsstand price of Finance, 1.30 euros, is about twice as high as that of a general daily, not an unusual ratio for a business publication.

\begin{tabular}{|l|l|}
\hline \multicolumn{2}{|c|}{ Table 2: Finance Advertising Rates in 2005 } \\
\hline Advertising Product & Cost \\
\hline Print ad open rate & 30 euros per 10-mm column \\
\hline Print ad, four-color, full-page & 3,200 euros \\
\hline Print ad, front-page & $500+$ euros \\
\hline Web banner & $415+$ euros per week \\
\hline Web section sponsorship & $205+$ euros per week \\
\hline "Business Morning" e-mail bulletin & $205+$ euros per week \\
\hline Web business-portrait expansion & 210 euros for six months \\
\hline Web surround session & 640 euros per day \\
\hline Web floating ad & $30+$ euro cost-per-thousand \\
\hline Rates available at <www.finance-on.com> \\
\hline
\end{tabular}

When Finance news products appear on other Slovenian media vehicles, as in the case of Finance's television broadcast, money does not change hands. Rather, the relationship is what might be called symbiotic (Croteau \& Hoynes, 2002). "We don't pay them; they don't pay us. We have exclusive news that television does not have. They are interested in our editorial material. We don't have funds to finance our own TV station, which, for example, Financial Times has. We will never have that because our market is not a global market. So we have to... be more inventive" (Frankl, 2004).

The extension of Finance's content distribution capabilities through collaboration with other media is not just Frankl's philosophy but the philosophy of the Bonnier group: "You should consider yourself as a service company giving your audience the service it pays you for, and you disseminate this service [through] different media. [These] media will distribute hot news to the audience; this will give more value added than print," Frankl said (2004).

One challenge Finance does not face, financially and otherwise, which the major dailies do, is funding international news coverage. Having reporters travel to other countries is not part of its agenda. "We are local. We cannot replace the International Times. We find the Slovenian perspective." The newspaper does use stringers and other "collaborators" to augment information provided by Reuters and Bloomberg information services, Frankl said. 
In terms of economic viability, Finance currently earns a profit of about five to six percent. Bonnier's DI division targets an 18 percent return on investment, and Frankl believes that Finance is moving in the right direction to eventually achieve this target. Frankl equivocated a bit concerning how Finance salaries compare with those of competitors. "Maybe we pay them a little less. Maybe, maybe not.... We have to compete with big newspapers on the labor market, so, yes, we have to pay." In any case, operating in Europe, the company is obliged to offer its employees health benefits.

\section{Newsroom Perspectives and Practices}

The researchers' interest in Finance was piqued by comments in an interview with a Slovenian university professor concerning its unique business model. Consistent with the objectives of our broader study, our interviews at Finance focused on the state of Slovenian journalism and Finance's role within this broader landscape. The primary themes addressed below concern the overall quality of journalistic practices - Finance's vis-à-vis Slovenia's major news dailies - and perceived constraints influencing journalistic quality. We start by presenting the views of Frankl, the aggressive managing editor of Finance, and then contrast his views with observations and comments provided by a variety of sources including Slovenian journalists, officials and scholars.

\section{Quality Journalism: Public Interest or Interesting the Public?}

"People need honest information; they want to exchange views. And newspapers are an important infrastructure for that," as Frankl said. "Quality" in journalism is often interpreted to mean media supporting "public interest" in preference to "what interests the public" (Johnson, 2004; McChesney, 1999). As former Chairman of the FCC Newton N. Minow famously commented, "What do we mean by 'the public interest'? Some say the public interest is merely what interests the public. I disagree" (Minow \& Lamay, 1995). Siebert, et al (1956) would identify this concern with public interest as social responsibility theory, a modification of libertarian theory of the press. The various theories of the press are discussed in the literature review section of this paper. For the Finance editor, quality journalism entails both. After all, a newspaper must be compelling enough to be consumed in order to maintain demand and circulation, or it won't have any effect on society at all.

The traditional major dailies in Slovenia feature longer stories and grayer pages, whereas Finance, printed on pale-pink paper, runs many short stories, photos on every page, charts and graphs, and bright-red section headings. The contrast is intentional. For Frankl deficiencies in quality of journalism as practiced in Slovenia have multiple causes: political and financial pressures, outmoded routines and lack of motivation, the latter of which may be legacies of 40plus years of socialist rule (Frank1, 2004; Ministry of Information, 2004; Slovenian Journalist, 2004). These factors lead to two major problems: circumscription of what is covered and diminution of what is read.

Direct political pressure on journalists in Slovenia is much less now than under socialism. Journalists no longer need fear that if they "go too far" the police will come to the door, as one interviewee put it. However, if coercive political pressure has lessened in the past decade, more subtle political influence and financial pressure have been noted.

"What is worse, I don't know: private monopoly or state-owned monopoly," Frankl said (2005). There can be combinations of political and financial pressure in a system where there are strong ties between leading political and business interests, where heads of the largest Slovenian companies hold chairs on media governing boards (Hrvatin et al., 2004, p. 477). For Frankl the way to avoid this local politico-financial grip is investment from outside national borders. He endorses foreign investment in Slovenian journalism, even when it comes from a large conglomerate. For 
him, some academicians' concerns about threats of foreign ownership are "typical Central European" foolishness prompted by fear of stakeholder power's affecting editorial autonomy. "The true threat is local corporate monopolies and state-owned corporations," he said (Frank1, 2005).

For Frankl, issues of political and financial influence are not theoretical. They impinge on the day-to-day operation of his newspaper and directly impact the quality of journalism, although his views regarding privatized news media and the consequences of foreign investment may be at odds with accepted wisdom. There is a Slovenian political leader now, he said, "who tries to pose himself as a strong leader, and he has some similarities... to Berlusconi in Italy.... Those two guys exercise their power in different ways because Berlusconi owns the media and in our case he doesn't own the media but he does own the media!" (Frankl, 2004). Frankl's company's owner, Bonnier AB of Sweden, he said, has given Finance autonomy from "local centers of power, from the influence of politicians and advertisers. Yes, we still feel pressure, but if it were Slovenian corporate pressure, then it might be more effective" (Frankl, 2005). Thus, in Frankl's view, plurality of voice is enhanced by external financial investment; "the emergence of new daily papers becomes more difficult if the law limits maximum newspaper ownership percentages" (Frankl, 2003).

In commenting on the quality of Slovenian journalism, Frankl said if the typical Slovenian journalist finds out something irregular is going on, he or she is unlikely to report on it if the information was not disseminated through proper means, "and a press conference is considered to be proper. It's very easy to report honestly on the events of the previous day: 'He said that, she said that.' This is a press conference," Frankl said. But it is not enough. This restricts the range of stories covered. It does not educate or enlighten or provide useful insight or analysis.

Frankl opines that poor-quality journalism exists because it is relatively easy to produce. This circumstance reflects professional routines of the communist era when reporters were not accustomed to conducting aggressive investigative journalism. Currently Slovenian journalists "are not very controversial because they like their quality of life which is at the moment pretty high" (Frankl, 2004). An applicable American idiom might be, Why rock the boat? Until a couple of years ago, the Slovenian press was reluctant to criticize the government, individual politicians or corporations, Frankl said. "Something really, really bad would have to happen for most newspapers to publish a story on corruption in a state-owned company which advertises with their newspaper... They are aware of corruption, but they don't write about it, because it would mean trouble with management of the media, so they don't care. It takes a lot of editorial stamina to criticize on a personal level. Why should you be a revolutionary if everything [in your personal life] is fine? They work from 9 to 5, they go home, they have their lives, they travel, fine. They have a good life."

He perceives his publication to have helped diminish that work-style barrier. "We started a new culture... one that keeps its distance from special interests.... We publish stories on some actual corruption in some state-owned company, and nobody else publishes that. They publish a story on corruption in a state institution but not where advertisers are." Has Finance ever lost advertisers due to failure to yield to their demands? "Yes, but they come back..." They return because they recognize Finance as a valuable vehicle for reaching their target consumers.

Testifying to the business daily's tenacity or to what Frankl calls "editorial stamina" is a January 2005 lawsuit involving Finance. Varis-Lendava, a Slovenian manufacturer of bathroom fixtures and likely a potential advertiser, sought a court order to prevent Finance from reporting on a lawsuit pending against it in Augsburg, Germany. So Finance management found itself in court but seemed confident of prevailing ("Business Daily Finance," 2005).

Although some journalists interviewed in the authors' broader study admitted that Slovenian journalists censored themselves, Frankl was proud to say, "We don't practice self-censorship." 
And if news sources are unhappy with the paper's reporting? "Well, we 'kill' sources. If he doesn't like it, then you just 'kill him' and you go to another who will talk to you. I have killed quite a few sources." Frankl said this philosophy was "partly introduced" by the newspaper's Swedish owners, adding that "it had to be this way" because Bonnier owns newspapers in multiple ex-socialist countries including Latvia, Estonia, Lithuania, Poland and Russia, and it seeks to uniformly apply a new journalism standard in these emergent democracies (Frankl, 2005).

Asked for an example of its editorial perspectives and quality in-depth reporting, Frankl noted his newspaper's editorial support of European Union accession. "We were very 'pro.' We did a big supplement on that. We were pro and also did quite some work on explaining what the role of the European Union is, what will happen... how our lives will change, how business will change." The newspaper published a special educational supplement on the EU and membership implications one week before the accession. That edition of the paper, 24 April 2004, was 56 pages. Asked if his country's journalists generally educate [rather than just inform] readers, Frankl said, "I don't think Slovenian newspapers educate [readers] a lot. Education means more work... To educate, you have to first want to educate. You have to be more vivid, write better, give more historical background, draw timelines, fight for attention. I have examples of newspapers we can go to," he said, walking from his office into the newsroom to point out other publications featuring long, gray columns of text. "They are just boring. Why on earth should they do that? [There is] no need to do that."

In writing style, most Slovenian newspapers tend to emulate traditional, old-style Central European newspapers. Delo, Slovenia's largest daily, "models itself after German newspapers..." (Veteran Journalist, 2004). "The results are lengthy, wordy articles and gray pages, not appealing to young and busy readers.... And it's also boring," Frankl insisted, and boring will not survive (Frankl, 2004). Such newspapers will die, he said, because they are written in a traditional European manner, with lengthy text which does not appeal to today's readers. This old style is not necessarily tied to political ideology. Journalism can be dry and boring under communism or capitalism, Frankl said. For example, he said, "the [German] Frankfurter Algemeine is very communist... and very boring." Long articles are often an excuse to write badly." Frankl is passionate on this subject, predicting that Slovenian newspapers as well as traditional German newspapers will need to "invest more into making communication more efficient.... They are boring, and they will have to change. And this will be a problem. It will be a process." Print media "just have to adapt to the fact people have less time to read," he said. "They will have to introduce new solutions" (Frankl, 2004).

\section{Further Perspectives on Finance}

If Frankl believes he has found the optimal formula for Slovenian journalism, not everyone agrees. Some observers find Finance a bit sensationalistic. It is less formal in writing style than its competitors. It may even be perceived as "yellow" by some journalists, Frankl admitted. Another journalist interviewed for this study commented that Finance was "quite tabloid in style" but "not really yellow," observing that it may occasionally print gossip but "sometimes the gossip turns out to be true." And Finance "does have some good sources," that journalist added (Slovenian Journalist, 2004). A Slovenian Ministry of Information employee commented that Finance is "more or less yellow," adding that, "it is true that they tackle almost every relevant topic" but that its reporting is too "sensationalistic" and "bombastic" for it to be regarded as a serious financial paper. This interviewee felt the newspaper needed to offer deeper analysis of problems (Ministry of Information, 2005). Like the journalist, he tempered his criticism with a compliment: "There is no doubt that [Finance] has some very capable and eminent columnists which are a sort of a counterweight to the general journalistic practice." Finance's approach may be at the forefront of a national trend. A reporter from a major Slovenian daily said he thought and indeed hoped that 
reader interest in shorter stories would prove to be a short-lived phase and that the public would eventually come to appreciate in-depth reporting again (Slovenian Journalist, 2004). However, he admitted that his publication already may be imitating Frankl's; it probably "uses more illustrations and graphics [now] because Finance does," he said.

Frankl of course does not consider his newspaper to be yellow. But he does acknowledge entertainment as one his publication's roles. Is this the necessary alternative to traditional "boring" journalism: "infotainment"? There will be infotainment, Frankl said. But that is not his focus. "Our market niche is honest journalism."

Whatever its qualities, Finance may be influential in a vital market segment. It is the only daily Slovenian newspaper focusing primarily on financial and economic issues and is "therefore a major opinion maker... because it has no noteworthy comparison [competitor]," a Ministry of Information official said. "Information provided in Finance very often has direct impact on the financial markets in Slovenia. The majority regard it as a credible information source."

Evidence that Finance does produce quality reporting is that young journalists do aspire to work there (Slovenian Journalist, 2004). Like Mladina, a historically young and rebellious newspaper, Finance is noted for "opening up important stories," a phrase Slovenians use similarly to the American "scoop." One Finance employee (Slovenian Journalist, 2004) commented, "We have no competitors in print media. They try, but they do not have the same frame of mind. Our news is quick and fast." The editor-in-chief claims to have reporters who "naturally want to do good journalism. I always say, 'Write what you want to write, just ask the other side what they want to say, realize the ethics, do good work, and nobody will inhibit you if your work is fine.' We don't have untouchables" (Frankl, 2004).

When discussing his concern about the lack of entrepreneurial spirit at Slovenia's major dailies, Frankl cited as an example his inability to find a Slovenian newspaper on the newsstands on a European holiday, 31 October 2003. Neither was there a Croatian or Italian daily to be found. "The only paper I could buy was Kleine Zeitung [an Austrian paper]. We protect our comforts," Frankl complained. "I hope it will never again be like that."

His view is not universally popular. A younger reporter interviewed for this study (Slovenian Journalist, 2004) observed that in this regard, there are two types of journalists, those who write easy stories and leave work at 3 p.m., and those who labor until 9 p.m. or later. The difference may be generational: there are indications that older journalists may be less dedicated. Those who were reporters under communism may "still have this matrix." However, this young interviewee, who began his journalism career post-independence, opined that perhaps Frankl had a "hard capitalist" viewpoint whereby workers should "leave their souls on the work desk." An accomplished journalist himself, the young reporter added, "I don't believe that... We deserve our day [holiday] free." Besides, he added, "if the stock exchange is closed, there is no news to fill." Similarly, a Slovenian Journalists Union employee lamented a perceived change in ethos brought about by privatization and westernization: a chipping away at the old culture of community, commiseration and appreciation for leisure in favor of competitive capitalism (SNS, 2004).

\section{Interpreting the Finance Case}

This onsite study has investigated the journalism philosophy and practice of a specific, specialty newspaper, Finance. The previous sections provide a comprehensive description of the publication and present key informants' views regarding Finance and the role it plays in the Slovenian media space. While any type of writing necessarily represents an interpretive act, transparency was the objective of the description. The authors sought to faithfully present the perceptions and understandings of study participants and to minimize interpreting their meaning. In this section we do offer an explicit interpretation of the Finance case by seeking to juxtapose the descriptions 
of this particular case with broader narrative discourses associated with global media studies and theories of the press. We describe how we employ relevant literature to make sense of the Finance case and employ the case to help illustrate the literature.

The authors are most interested in the quality of hard news reporting, believing an aggressive and uncensored press to be an essential prerequisite to the establishment of a legitimate democratic government. The case of Finance appeared noteworthy because early reports suggested the publication was making a significant contribution to the quality of Slovenian journalism, despite its foreign ownership.

The authors acknowledge that a single case study does not prove nor disprove theory. The purpose of descriptive cases is to provide insight on the experience lived in a particular context. Our sense is that theory can usefully contribute to an interpretive understanding of the world only when balanced with an accretion of understanding derived from particular lived experiences.

Thus, the intertwined themes we wish to explore within the context of the Slovenian print media space and the Finance publication include:

- The degree to which the Finance business model and journalistic style conform with archetypical theories of the press.

- The implications of changing readership tastes for quality of journalism.

- The implications of profit-based news production on journalistic quality.

- The implications of foreign ownership for journalism quality.

We explore these themes at a time when newspaper readership in western democracies is in decline. Circulation has been decreasing in the United States at about one percent per year since the 1970s (Douglas County Libraries, 2001; Groves, 1997). Between 1999 and 2003 European circulation declines ranged from 1.3 percent in Sweden to 8.1 percent in Germany, 12.9 percent in Austria, and 16.76 percent in Portugal (Finfacts, 2005). Loss of readers directly decreases circulation income and indirectly reduces advertising income. Readers are a newspaper's raison d'être. Whatever the reasons for the readership decline, whether they be anti-intellectualism, competition from other media or activities, laziness or a desire to be better entertained, circulation must be addressed.

\section{Which Theory of the Press Best Fits the Finance Experience?}

If a newspaper were a factory - indeed it is sometimes referred to as a plant - its output would be some combination of news, advertising and/or entertainment content. Major inputs or resources required to produce and distribute this product would be: (1) the stream of events constituting the source of "news" to be published; (2) economic resources; and (3) human effort and talent. However, the organization and control of these factors of production vary systematically from one society to another. These societal variations are significant given their recognized impact on content and quality of the product and the role the press is perceived to play in society.

Research dating back to at least 1956 has sought to make sense of various systems of organizing and controlling the press. The seminal work of Siebert et al in 1956 proposed four theories or forms of press control and use: Authoritarian, Soviet Communist, Libertarian and Social Responsibility. Siebert et al hypothesize that "the press always takes on the form and coloration of the social and political structures within which it operates" (Siebert et al., 1956, p. 1).

Authoritarian, the oldest of the theories, conceived of the press as the product of a few wise men... near the center of power." Under Authoritarian theory, "media are responsible to the state but not owned by the state" (Segvic, 2005, p. 9). Examples of countries "where press control is 
complete" from the 1950s include Spain during the era of Generalissimo Francisco Franco, China and Portugal as well as Yugoslavia, according to the International Press Institute report to the United Nations (Siebert et al., 1956, pp. 148, footnote 14).

Soviet Communist theory, grounded in Marxist determinism, removed the profit motive and actively used the press to further its ideology. Under Soviet Communist theory, media are of the state, owned by the government (Segvic, 2005, p. 9), not just controlled by it.

Libertarian theory, in contrast, contends that "the right to search for truth is one of the inalienable natural rights of man" and that the press is an instrument to enable the masses to discover and evaluate truth for themselves (Siebert et al., 1956, p. 3).

Siebert identified the Social Responsibility theory as a model that developed more recently than the above-mentioned press theories; it holds that the press "enjoys a privileged position" accompanied by obligations. Six tasks describe the newer theory including: serving the political system by providing information, enlightening the public to make it capable of self-government, protecting individual rights by serving as a watchdog over the government, promoting the economy by bringing together buyer and seller through advertising, providing entertainment, and maintaining financial self-sufficiency (Siebert et al., 1956, pp. 73-74).

While Siebert, et al's work is still recognized and cited, the four theories of the press have undergone criticism and elaboration reflecting changing historical circumstances and deeper examination of economic, social-cultural and political forces influencing if not constituting journalistic practice. For example, Hachten (1987) proposed five concepts of the press: Authoritarian, Western, Communist, Revolutionary and Developmental (or Third World). Of particular relevance, his Western Concept describes a free press with "the right to talk politics" found in Western nations that enjoy protection of individual civil liberties, high average per capita income, democracy or at least opposing political parties, "an established tradition of independent journalism" and "sufficient capital or private enterprise to support media of news communication" (Hachten, 1987, p. 19).

Picard criticized the Siebert et al theory as inadequate for the world of the 1980s. He felt that Authoritarianism as described by Siebert was found "only in some nations in Latin America, Africa and Asia with strong governments headed by dictators and monarchs" and that the Communist model was practiced "predominantly in Eastern Europe, China and a few communist nations in the Third World" (Picard, 1982/83, p. 25). Picard asserted that "Anglo-American libertarianism" is premised on transition from state market control to commercial market control, a move presumed to be liberating. However, he clearly saw that "the press can become subservient to market forces that can also restrict freedom" (Picard, 1982/83, p. 27). Picard points to a new northern European model called Democratic Socialist Theory of the Press which calls for state intervention if required to prevent monopoly and promote media plurality of a vital public utility. This view "incorporates Libertarian, Liberal and Socialist views of press freedom," and its main proponents are in Scandinavia.

More recently, Segvic (2005, p. 10) proposed a Post-Communist Theory of the Press based on her analysis of three Croatian newspapers. She found the Croatian press in transition "suffocated by censorship and self-censorship that resulted from the pressure of the new regimes."

Of the major theories of the press proposed by Siebert et al and expounded upon by subsequent researchers, the case of Finance business daily newspaper best exemplifies the Social Responsibility reflective of the western European journalistic values of it majority owner, Bonnier. Finance did not exist until 1992 and thus as an entity did not experience the highly controlling pressures of a strict Authoritarian or Soviet Communist model. The Social Responsibility theory, however, fits the Finance case well in light of Siebert's six components of a Social Responsibility 
approach: serving the political system by providing information, enlightening the public to make it capable of self-government, protecting individual rights by serving as a watchdog over the government, promoting the economy by bringing together buyer and seller through advertising, providing entertainment, and maintaining financial self-sufficiency (Siebert et al., 1956, pp. 73-74). Relative to other journalism products in Slovenia, Finance not only exhibits but embraces the latter two of these elements, providing entertainment and maintaining financial self-sufficiency. Regarding entertainment value, its publisher unabashedly seeks to produce an interesting and saleable product. Regarding financial viability he not only accepts the necessity of international investment, he welcomes it as a source of political independence as well as economic selfsufficiency. Thus, while scholars have criticized the Siebert et al theory and sought to update and internationalize it, it offers an accurate and adequate model for Slovenia's business daily newspaper Finance.

\section{Changing Readership Tastes}

Observers have noted changes in readership preferences with the rise of market-driven media (Ansolabehere \& Iyengar, 1997; Downing, 1996; McChesney, 1999; Postman, 1986). Research provides evidence of changing readership habits and preferences in formerly socialist nations, where the typical socialist reader had "a habit of reading newspapers that he probably got from his parents" and was willing to learn about events "from a serious newspaper, with solid expertise and respectable opinions" rather than from the "yellow" press (Jones, 2002, pp. 365-366). In Russia younger readers are less interested in serious, old-style journalism; the new generation reader appears to prefer a paper with a "jazzier logo" and color photographs, a paper from which he "can learn about scandals, who's sleeping with whom, criminal stuff. Izvestia had tried to avoid these topics, but it's hard to do, because it's really easy to attract readers with this kind of coverage" (Jones, 2002, pp. 365-370). The Russian experience in this regard parallels what we observed in Slovenia. The most successful post-independence publication in terms of circulation and readership is Slovenske Novice, widely regarded as a tabloid-quality publication. Gossip, scandal and sensationalistic writing do sell papers and represent competition for serious news Whilies this paper leaves unaddressed issues concerning possible causes of these changes in readership taste, the Finance editor's view is that one cannot and need not resist what appears to be an inevitable change in reader tastes. It is hard to imagine that Frankl would ever have thought the ponderous German style of news writing was warranted, but he clearly believes that a continuation of such writing practices will spell the demise of dailies unwilling to change. He believes readers still want honest news reporting and analysis but no longer spend the time and intellectual effort required to extract desired information from ponderously written articles. His solution is more concise, precise and more entertaining presentation of hard news. As Schlesinger (1995, p. 110) points out, it has become merely "an analytical exercise" to try to "hermetically seal" information from entertainment.

\section{Market-Driven Media: News Demand, News Supply and News Quality}

Readership tastes are critically important to privately financed publishers. Seventy percent of $\mathrm{Fi}$ nance's revenues derive from advertising sales, and advertising rates are a direct function of market demographics and size. Thus, publications must produce something readers are willing to consume. Furthermore, publications must attract advertisers. Herman and McChesney (1997, pp. $189,190)$ express concern about this development. While acknowledging that "competition and the need to satisfy audiences ultimately compel the commercial media to 'give the people what they want," they contend that consumer choice is limited because program offerings are inevita- 
bly shaped by advertiser interests which "in turn feature entertainment, the avoidance of controversy, minimal public participation, and the erosion of the public sphere."

The seemingly inherent conflict between profit maximization and quality news production surfaced in our broader study of Slovenian journalism (Beachboard \& Beachboard, 2005). A participant in that study, a journalist at a major Slovenian daily, noted that although his publication had earned a 35 percent profit for the year, it was reluctant to fund international travel for its correspondents to cover important breaking news (Slovenian Journalist, 2004). Of course, such events are not unique to Slovenia; the reduction of newsroom investment and resultant coverage in the interest of profit maximization certainly has also been lamented in the United States (Just \& Rosenstiel, 2005).

Yet Frankl believes that good journalism is not at odds with good business; rather, he finds that good journalism is good business because the resulting product will be the most profitable over the long term. He sees "professional editing" as his strongest defense against pressure from politicians and advertisers, exemplifying the scholarly view that professional routines are a major factor in determining message quality (Croteau \& Hoynes, 2002). Herman and McChesney (1997, pp. 192-193) acknowledge some truth in this perspective and find that some reporters do "first-rate work, despite corporate control of the industry" but "in many critical areas this kind of journalism is the exception and has been discouraged by bottom-line pressures" because "each sector is expected to have a positive effect on the firm's earning's statement." They reflect that, given "the vagueness and flexibility of objectivity standards, professionalism... can only rarely override the imperatives of ownership and advertiser interests on bottom-line pressures."

\section{Foreign Ownership: Threat and Opportunity}

To the consternation of many media observers and scholars, the world is experiencing unprecedented growth of multi- or trans-national media conglomerates (Artz \& Kamalipour, 2003; Hollifield, 2001; Marques de Melo, 1988; Roncagliolo, 1994; Schlesinger, 1995). In former Soviet bloc economies, "a lack of domestic capital has led to an influx of foreign capital" by Western European media corporations where investment has been judged to be potentially profitable (Schlesinger, 1995, p. 113). The Hungarian experience is particularly notable as foreign ownership of principal media in Hungary rapidly grew to nearly 80 percent (Ognianova, 1997, p. 8), and participants in this Slovenian study noted they did not desire to follow the Hungarian model of privatization (Slovenian Journalist, 2004). While capital influx has occurred in Slovenia, legislative restrictions slowed the entry of foreign capital into the Slovenian market (Karlekar, 2004, p. 167).

Foreign ownership as well as internationalization of media products has been particularly evident in print media. For example, papers such as The Financial Times, The International Herald Tribune and The Wall Street Journal began "consciously addressing international political and economic elites in the nearest thing we have to a European lingua franca, namely English," and the "quality press in various countries have also begun to produce 'European' supplements, compiled from reports and features selected from like-minded newspapers across the continent" (Schlesinger, 1995, p. 111). Foreign media ownership and participation elicits multiple concerns. The primary issue with respect to this study is potential implications of foreign ownership on the quality and quantity of local news coverage (internal to a particular country). The fear is that foreign ownership will impose homogenized versions of international news slanted toward the interests of business and political elites while ignoring aggressive coverage of local issues such as corruption and government/business collusion.

Yet in the case of Finance, a more virtuous dynamic appears to have occurred. Frankl attributes his ability to pursue aggressive investigative journalism at least in part to foreign capital and 
ownership. Given the levels of direct and indirect government and big-business ownership of media currently existing within Slovenia, powerful pressure can be covertly and overtly brought to bear on the press (Hrvatin et al., 2004). Frankl credits the corporate philosophy and financial backing of a Swedish owner with helping his department maintain the "editorial stamina" required to stand up to advertiser pressure. However, it must be acknowledged that Finance's experience may be atypical in that Bonnier is family-owned, and there are no public stockholders to satisfy.

This study is not constrained to simply trusting Frankl's assertion in this respect. Rather, evidence of Finance's aggressive investigative reporting was corroborated by study participants working at competing publications and government ministries. While these sources did not always appreciate Finance's reportorial style, there were multiple acknowledgements of its having "scooped" the competition by breaking important news stories.

\section{Study Limitations and Directions for Future Research}

Single-site case studies do not provide grounds for generalization, and the authors do not see this paper as implicitly or explicitly making such a claim. Our approach intentionally focuses on the particular and idiosyncratic, it necessarily reflects the biases of key informants and biases in phrasing questions and selecting responses for inclusion in this report. Without attempting to engage in a philosophical debate concerning the scientific merits of such an approach, we obviously believe single-site interpretivist analyses can contribute to the body of knowledge.

That stated, we wish to re-emphasize that this paper is not intended to advocate global media ownership nor assert that market-driven journalism is necessarily preferable to other models. We acknowledge that a significant limitation of this study is that it does not provide grounds for generalizing.

Additionally, the authors do not speak Slovenian and limited resources available to support this study. This limitation was minimized by the English-speaking proficiency of our key informants. However, this certainly limited our ability to directly examine Finance's Slovenian language products.

Furthermore, some reviewers perceived over-reliance on the perspective of managing editor Peter Frankl. We acknowledge this limitation and accept that as a consequence of our selected research approach as described above. However, we note that Frankl's assertions were not necessarily accepted as the only legitimate perspective. We include the views of knowledgeable government and academic sources and members of the competing press. We did speak with a member of the editorial staff who felt free to disagree on an aspect of Finance's business strategy with respect to online publishing, but substantially agreed with the Frankl's broader views. It would have been advantageous to meet with a sample of Finance correspondents; our resources did not permit it.

While recognizing the limitations of the current study, we believe that it does lay the groundwork for future investigations. Our examination of Slovenian journalism generally and the Finance case specifically suggests a need for additional work in refining press theories or models. Existing frameworks do not easily accommodate our observations, which leads us to think that a more comprehensive and granular framework might be developed. In particular we find that current press theories are ambiguous in discriminating between political and economic authoritarianism. We perceive a need for the development of a more comprehensive model and its empirical assessment at both the national and organizational levels. 


\section{Conclusion}

The authors have sought in this paper to construct a narrative report that contributes to readers' understanding of the philosophy and operation of a particular Slovenian media product that, while based primarily on the perspectives of the managing editor, also reflects the understanding of competing journalists and informed Slovenian academics and government officials. Implicit in this effort is a conviction that such a narrative provides not only a useful object of reflection for study participants but observations and insights that readers might usefully apply to the analysis of their own distinct concerns. It is understood that Slovenian history and culture as well as the unique individuals and circumstances involved in Finance's creation and operation preclude our ability to draw broad generalizations from this case. However, we believe that one can still gain valuable insights from this case.

The majority of research addressing media privatization, consolidation and globalization is critical in its orientation, maintaining that commercialization and foreign ownership of local media have disastrous potential or actual effects in terms of public interest and the maintenance of local culture. We do not contest these meta-narratives on the basis of a single case. We do, however, argue that we have revealed a specific case at odds with the conventional wisdom of the meta-narratives. And, harking back to our opening quote, we find reason to hope that capitalistdriven journalism need not be a fruitless means of funding journalism in the public interest.

Whether the reader agrees with Frankl regarding the unappealing nature of the traditional German reporting style, or is shocked by Bonnier's 18 percent profit target, or disdains the use of bold graphics and colors, or is quite comfortable with the notion that a newspaper might not publish on a national holiday, one must acknowledge that Finance is a for-profit publication that contributes to plurality of voice in the marketplace of ideas, making a contribution to public interest and democratic debate. Not everyone likes it or approves of it, but Finance does seem to exemplify the shape of the future. As one journalist interviewed for this study commented, "It will be interesting to see if it stays a mix of hard news and yellow press.... I believe they will follow this uneasy balance in the future."

\section{References}

Altheide, D. L., \& Johnson, J. M. (1994). Criteria for assessing interpretive validity in qualitative research. In N. K. Denzin \& Y. S. Lincoln (Eds.), Handbook of qualitative research (pp. 485-499). Thousand Oaks: Sage.

Ansolabehere, S., \& Iyengar, S. (1997). Going negative: How political advertisements shrink and polarize the electorate. New York: The Free Press.

Artz, L., \& Kamalipour, Y. R. (Eds.). (2003). The globalization of corporate media hegemony. New York: State University of New York Press.

Beachboard, M. R., \& Beachboard, J. C. (2005, 28 May). Newspapers in Slovenia: (Re)constructing print journalism on the fault lines of history. In M. E. Grabe (Chair), Journalism, politics and in session: Journalism, politics and democracy: International perspectives. Journalism Studies Unit conducted at the International Communication Association. New York City.

Bervar, G. (2001). Foreign capital in Slovenian media. Accessed 3 March 2005 from http://www.medienhilfe.ch/Monitor/SLO/MOL01.pdf

The Bonnier Group. (2006). Bonnier AB. Retrieved 25 February 2006, from http://www.bonnier.com/

Business daily Finance makes court appearance tomorrow. (2005). Slovenia Bulletin. Accessed 16 March 2005 from http://slo-bulletin.blogspot.com/2005 01 23_slo-bulletin_archive.html

Campbell, J. C. (1980). Tito: The achievement and the legacy. Foreign Affairs, 58(5), 1045-1059. 
Creswell, J. W. (1994). Research design: Qualitative and quantitative approaches. Thousand Oaks: Sage.

Croteau, D., \& Hoynes, W. (2002). Media/society: Industries, images and audiences ( $3^{\text {rd }}$ ed.). Thousand Oaks, CA: Pine Forge Press.

Demers, D. P. (1999). Global media: Menace or messiah? Cresskill, NJ: Hampton.

Douglas County Libraries. (2001, 15 August). Newspaper readership. Accessed 16 March 2005 from http://www.douglascountylibraries.org/aboutUs/index.php?pageName=LaRue081501

Downing, J. D. (1996). Internationalizing media theory: Transition, power, culture (reflections on media in Russia, Poland and Hungary 1980-95). London: Sage Publications.

Eisenhardt, K., M. (1989). Building theories from case study research. Academy of Management Review, $14(4), 532-550$.

Finance. (2005). Finance Mission Statement. Accessed 20 March 2005 from http://www.finance-on.net/english?mode=daily

Finfacts. (2005, 28 November). Accessed 3 March 2005 from http://www.finfacts.com/blog/2004 11_28 finfactsarchive.html

Frankl, P. (2003, November). Die Zukunft der Slowenischen Tageszeitungen Nach der EU Erweiterung (The Future of Slovenian Daily Newspapers after EU Expansion). [Presentation to Austrian and Slovenian business leaders.] Ljubljana, Slovenia.

Frankl, P. (2004, June). Personal interview (Perspectives on Slovenian Media). Ljubljana, Slovenia.

Frankl, P. (2005, Spring). Telephonic and e-mail communications (Perspectives on Finance Newspaper and Slovenian Media).

Freedom House. (2003). National readership survey. Accessed 3 March 2005 from http://www.freedomhouse.org/research/nattransit.htm

Geertz, C. (1985). Local knowledge: Further essays in interpretive anthropology. New York: Basic Books.

Groves, M. E. (1997). Business outlook. Accessed 16 March 2005 from http://www.naa.org/presstime/9709/forecast.html

Hachten, W. A. (1987). The world news prism: Changing media, clashing ideologies. Ames, Iowa: The Iowa State University Press.

Hamelink, C. (1994). Trends in world communication: On disempowerment and self-empowerment. Penang, Malaysia: Southbound.

Herman, E. S., \& McChesney, R. W. (1997). The global media: The new missionaries of corporate capitalism. London: Cassell.

Hollifield, C. A. (2001). Crossing borders: Media management research in a transnational market environment. The Journal of Media Economics, 14(3), 133-146.

Holstein, J. A., \& Gubrium, J. F. (1994). Phenomenology, ethnomethodology and interpretive practice. In N. K. Denzin \& Y. S. Lincoln (Eds.), Handbook of qualitative research (pp. 262-272). Thousand Oaks: Sage.

Hrvatin, S. B., Kucic, L. J., \& Petkovic, B. (2004). Media ownership: Impact on media independence and pluralism in Slovenia and other post-socialist European countries. Ljubljana, Slovenija: Mirovni Institut (Peace Institute: Institute for Contemporary Social and Political Studies).

International Press Institute (IPI) (2004). [Online]. Accessed 22 October 2004 from http://www.freemedia.at/Congress04_Warsaw/Warsaw main.htm\#Programme

Johnson, N. (2004, 9 December). Media concentration: An historical perspective. Accessed 20 March 2005 from http://www.nicholasjohnson.org/writing/masmedia/FCCForum.html 
Jones, A. (2002). The Russia press in the post-Soviet era: A case study of Izvestia. Journalism Studies, 3(3), 359-375.

Just, M., \& Rosenstiel, T. (2005, 26 March). All the news that's fed. The New York Times [Online]. Accessed 26 March 2005 from http://www.nytimes.com/2005/03/26/opinion/26just.html?ex=1112504400\&en=ad9674efe9964d78\&ei $=5070$

Karlekar, K. D. (2004). Freedom of the press 2004: A global survey of media independence. Accessed 3 March 2005 from http://freedomhouse.org/pfs2004/pfs2004.pdf

Lydall, H. (1987). Yugoslav socialism: Theory and practice. New York, NY: Oxford University Press.

March, J., Sproull, L., \& Tamuz, M. (1991). Learning from samples of one or fewer. Organization Science, 2(1), 1-13.

Marques de Melo, J. (1988). Communication theory and research in Latin America: A preliminary balance of the past twenty-five years. Media, Culture and Society, 10(4), 405-418.

McChesney, R. W. (1999). Rich media, poor democracy: Communication politics in dubious times. Chicago: University of Illinois Press.

McManus, J. H. (1994). Market-driven journalism: Let the citizen beware? Thousand Oaks, CA: Sage Publications.

McPhail, T. L. (1987). Electronic colonialism: The future of international broadcasting and communication (SAGE Library of Social Research). Sage Publications.

Miles, M. B., \& Huberman, A. M. (1994). Qualitative data analysis: An expanded sourcebook. Thousand Oaks, CA: Sage.

Ministry of Information, Slovenia (2004, June). Personal interviews (Perspectives on Slovenia Media). Ljubljana, Slovenia.

Ministry of Information, Slovenia (2005, March). Telephonic and e-mail communications (Perspectives on Finance newspaper).

Minow, N. N., \& Lamay, C. L. (1995). Abandoned in the wasteland: Children, television and the first amendment. HarperCollins.

Ognianova, E. (1997, June). The transitional media system of post-communist Bulgaria. Journalism and Communication Monographs, 162.

Patton, M. Q. (2002). Qualitative research and evaluation methods ( $3^{\text {rd }}$ ed.). Thousand Oaks, CA: Sage Publications.

Picard, R. G. (1982/83). Revisions of the 'Four Theories of the Press' model. Mass Communication Review, Winter/ Spring, pp. 25-28.

Postman, N. (1986). Amusing ourselves to death: Public discourse in the age of show business. Penguin Books.

Roncagliolo, R. (1994). Communication and development: The Latin American challenge. In C. J. Hamelink \& O. Linne (Eds.), Mass communication research: On problems and policies (pp. 267-275). Norwood, NJ: Ablex.

Schiller, H. I. (1976). Communication and cultural domination. New York: M. E. Sharpe.

Schlesinger, P. (1995). Tensions in the construction of European media policies. In N. Morris \& S. Waisbord (Eds.), Media and globalization: Why the state matters (pp. 95-115). Oxford, England: Rowman \& Littlefield Publishers.

Segvic, I. (2005, 28 May). The media's post-communist purgatory: A conception of the post-communist theory of the press. In M. E. Grabe (Chair), Journalism, politics and democracy: International perspectives. International Communication Association, New York City. 
Siebert, F. S., Peterson, T., \& Schramm, W. (1956). Four theories of the press. Urbana, IL: University of Illinois Press.

Slife, B. D., \& Williams, R. N. (1995). What's behind the research? Discovering hidden assumptions in the behavioral sciences. Thousand Oaks, CA: Sage Publications.

Slovenian Journalists. (2004, June). Personal interviews (names withheld) (Perspectives on Slovenian Media). Ljubljana, Slovenia.

SNS. (2004, June). Sindikat Novinarjev Slovenije (Union of Slovenian Journalists) Personal interviews (Perspectives on Slovenian Media). Ljubljana, Slovenia.

Stake, R. E. (1994). Case studies. In N. K. Denzin \& Y. S. Lincoln (Eds.), Handbook of qualitative research (pp. 236-247). Thousand Oaks: Sage.

Thompson, Kenneth. (1997). Media and cultural regulation. London: Sage Publications.

Tomlinson, J. (1991). Cultural imperialism: A critical introduction. Baltimore, MD.: Johns Hopkins University Press.

Veteran Journalist. (2004, June). Personal interview (Veteran Slovenian Journalist) (Perspectives on Slovenian Media). Ljubljana, Slovenia.

Yin, R. K. (1994). Case study research: Design and methods ( $2^{\text {nd }}$ ed.). Thousand Oaks, CA: Sage.

\section{Biographies}

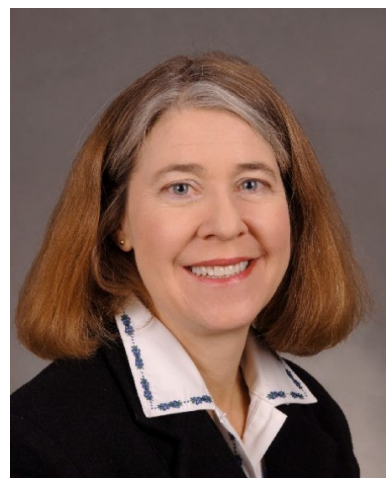

Martine Robinson Beachboard is an Assistant Professor of Mass Communication at Idaho State University in Pocatello, ID. She teaches courses in advertising and in mass communication and society. She previously taught with the University of Maryland European Division. Her research interests include international and intercultural journalism as well as media literacy.

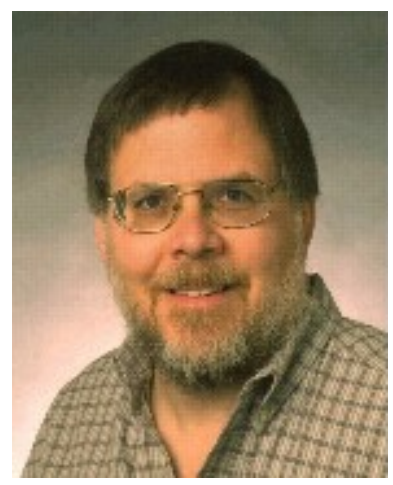

John Beachboard joined the Computer Information Systems faculty at Idaho State University in 2001. He completed the Ph.D. in Information Transfer and the M.S. in Information Resources Management at the School of Information Studies, Syracuse University. He holds an M.S. in Business Administration from Boston University and a B.S. in Public Administration from the University of Arizona. Dr. Beachboard has taught graduate courses in research methods, project management and IT use in business, and undergraduate courses in IT management and systems architectures. He has held staff and management positions developing, implementing and operating information and telecommunications systems for the Department of Defense. He is keenly interested in the development, application and effectiveness of information technology management policies in the private and public sectors. 